\title{
Archipel
}

ARCHIPEL Études interdisciplinaires sur le monde insulindien

$88 \mid 2014$

Varia

\section{Biographical Dictionary of Mercantile Personalities of Penang}

Claudine Salmon

\section{(2) OpenEdition}

Journals

Édition électronique

URL : http://journals.openedition.org/archipel/532

DOI : $10.4000 /$ archipel. 532

ISSN : 2104-3655

Éditeur

Association Archipel

Édition imprimée

Date de publication : 10 octobre 2014

Pagination : 216-217

ISBN : 978-2-910513-71-9

ISSN : 0044-8613

Référence électronique

Claudine Salmon, «Biographical Dictionary of Mercantile Personalities of Penang », Archipel [En ligne], 88 | 2014, mis en ligne le 10 septembre 2017, consulté le 25 septembre 2020. URL : http://

journals.openedition.org/archipel/532 ; DOI : https://doi.org/10.4000/archipel.532 
courageous. A small town, or perhaps just a prosperous village, does not necessarily need a vast "hinterland." Moreover, for later periods one may even turn the picture upside down: the small settlement on Singapore Island became an "adjunct" of some nearby area(s).

Historians often emphasize the importance of the Chola intervention (1025), although we practically know very little about the real course of this event. By contrast we know much more about the Yuan and their maritime activities. David Bade's Khubilai Khan and the Beautiful Princess of Tumapel (Ulaanbaatar 2002; republished Singapore 2013) gives a wonderful example of what one can extract from the sources. Moreover, Sinologists have divided the brief period of Yuan trade and politics in maritime Asia into different stages and perhaps one could try to relate these "sub-periods" to the fate of Temasik more systematically. Other ideas may be found in recent studies, for example Geoff Wade's "An Early Age of Commerce...," Journal of Southeast Asian Studies 40.2 (2009). In short, Miksic provides a long bibliography, but he leaves out some important titles: Hans Bielenstein's voluminous Diplomacy and Trade in the Chinese World, 589-1276 (Leiden 2005) for the tribute envoys, many Chinese works on early topics such as the missions by Zhu Ying and Kang Tai, Max Deeg's huge translation of Faxian's text, the Kedah monograph by Michel Jacq-Hergoualc'h, a long article by Johannes Kurz on Chinese texts dealing with Brunei / Borneo - to mention just a few examples. Miksic addresses all these topics, directly or at the side, therefore readers would have been grateful for recent "updates." Other possible additions concern the old works by Paul Pelliot, the monograph by Jacques Dars, some Portuguese studies dealing with the sixteenth century, and so on. One also wonders why his bibliography does not list the magnificently illustrated collection prepared by Aileen Lau and Laure Lau, Maritime Heritage of Singapore (Singapore 2005), which has much to offer for the period after circa 1500. This book is for general readers and scholars alike and follows similar intentions as Miksic himself, who wishes "to raise Singaporeans' awareness of the fact that the rise of their small island nation is not a recent historical accident...” (p. 23).

My comments partly stem from high expectations when reading Singapore and the Silk Road of the Sea. The archaeological sections are illuminating, indeed, and the way Miksic tries to align certain descriptive elements (found, for example, in the usual array of semi-historical Malay accounts) with the "underground" facts deserves admiration; but there are quite a number of other things, often technical in nature, that are not satisfactory. In conclusion, then, one has to state that Miksic's book reveals much zeal; it offers many archaeological details (perhaps too many for a general reader) and some interesting interpretations; it contains beautiful images, there is an index with important names, and there are useful maps as well; however, there is also a grey side, which makes it difficult to give a final assessment of this work.

Roderich Ptak

Loh Wei Leng, Badriyah Haji Salleh, Mahani Musa, Wong Yee Tuan \& Marcus Langdon (eds), Biographical Dictionary of Mercantile Personalities of Penang, George Town, Think City and MBRAS, 2013, 227 p. plates and maps. Foreword by Wang Gungwu. ISBN 978967-9948-659-2

This dictionary, which focuses on the mercantile male personalities who pioneered the 
growth of George Town from the end of $18^{\text {th }}$ century up to the mid- $20^{\text {th }}$ century, is the first of its kind. However the interest for local figures started much earlier when, in 1986, a book entitled Historical Personalities of Penang was published by The Historical Personalities of Penang Committee under the Auspices of Penang Festival'86, and an exhibition based on this publication inaugurated. This latter volume also included community and political leaders, civil servants, academicians, religious teachers and artists, and among them, a few prominent women, but the biographical sketches were not referenced.

The present book highlights the life of merchants and business people from all communities, including the Acehnese, Arabs, Armenians, British, Chinese, Eurasians, Indians, Malays, Parsees, Scottish. It has been prepared with great care, thanks to the contribution of twenty authors. The entries are introduced by an overview of the historical development of the island since the coming of the Portuguese to Malacca (pp. 4-8). It appears clearly that the trader and business community has formed a major pillar since the late $18^{\text {th }}$ century of the city, when Penang was made an entrepôt.

Then the editors in a note on the biographies (200) explain how they proceeded. Each entry begins with the surname, given name (Chinese names in Hokkien dialect, followed by characters, and also in Mandarin, transcribed in pinyin), date of birth and death, profession, occupation, major role in the society. It ends with references in abbreviated form, while full references are given in a general bibliography including public records, archives and archival materials, newspapers and magazines (in English, Malay, and Chinese), unpublished theses, papers and manuscripts, personal communications, books and journal articles (in English, Malay and Chinese), and internet sources. The use of a symbol in the index allows the reader to know if a personality is listed in the main entries (pp. 12-178) or in the brief biographical sketches (24 altogether, pp. 179-191) that is those for whom the biodata are not yet sufficiently documented, but who merit inclusion in the history of Penang. If we consider that in 1810 , the Indians represented some $30 \%$ of the population, Chinese $36 \%$, Malays and Arabs $25 \%$ and that in 1860, the Chinese became the majority in Penang, one would not be surprised to notice that they are also the best represented among the biographies.

Although this dictionary is still far from being exhaustive, as the editors admit, it does great service to the historians who want to deepen their knowledge on these personalities and their part in the making of Malaya and even Southeast Asia.

Claudine Salmon

Stefan Dietrich \& Margareta Pavaloi (eds), Flussaufwärts, Die Borneo Sammlung Hilde May, Heidelberg : Völkerkundemuseum der J. \& E. von Portheim-Stiftung (vPST), 2013, 200 pages, 283 ill., bibliographie.

Preuve d'un regain d'intérêt pour les arts et les cultures de Bornéo depuis quelques années ${ }^{1}$, ce catalogue d'exposition présente une collection formant un ensemble représentatif

1. Il faut citer les expositions récentes sur l'art des sociétés dayak, notamment la statuaire et la sculpture « Patong », organisée en 2007 au Museo delle Culture de Lugano (Suisse), à partir de l'importante collection d'art tribal Brignoni, léguée au musée (Patong. La grande sculpture dei popoli del Borneo, Milan, Mazzota, 2008). Puis, dans le même établissement en 2012 une exposition centrée sur les chapeaux de soleil de la province de Kalimantan Centre (Sapuyung. Cappelli cerimoniali del Borneo, Milan, Mazotta, 2012). En France, il faut citer l'exposition «Dayak et Punan : Peuples de la forêt tropicale » au Musée d'Art et d'Archéologie de Laon dans l'Aisne en 2006 - sans catalogue ; plus 